\title{
Containing Kosovo
}

\section{Gordon N. Bardos *}

The international community's five-year performance review of its efforts in Kosovo has come in, and the result is a failing grade. By almost any measure, the North Atlantic Treaty Organization (NATO), the United Nations (UN), Kosovo's own political leaders, and the myriad other organizations and states ostensibly struggling to foster peace, stability, human rights, and a multiethnic society in Kosovo have utterly failed in their efforts. As Human Rights Watch summed up the situation in Kosovo in the wake of the March 2004 pogroms in which twenty people were killed, four thousand were driven from their homes, and thirty-six Christian churches and monasteries were destroyed:

The security organizations in Kosovo-KFOR, UNMIK international police, and the KPS - failed catastrophically in their mandate to protect minority communities during the March 2004 violence.... The international community appears to be in absolute denial about its own failures in Kosovo. ${ }^{1}$

Yet, while representing the most serious outbreak of violence in Kosovo in the five years since NATO and the UN assumed responsibility for the province, this violence was certainly not an isolated occurrence. In reality, ethnic minorities, in the words of a report issued jointly by the United Nations High Commissioner for Refugees (UNHCR) and the Organization for Security and Cooperation in Europe (OSCE), have faced an "unrelenting tide of violence" in the province since $1999 .{ }^{2}$ In a 2003 report, Amnesty International pointed out:

... minorities in Kosovo continue to be denied access both to their basic human rights, and to any effective redress for violations and abuses of these rights. Almost four years after the end of the war in Kosovo, despite the efforts of the NATO-led Kosovo Force (KFOR) and the UN Civilian Police (UNMIK Police) to provide security and protection, members of minority communities continue to both suffer and fear assaults by the majority community on their lives and property.... This climate of fear, insecurity, and mistrust ... has resulted in the effective denial of the right of ethnic minorities to enjoy freedom of movement in Kosovo. Additionally, those who are able to gain some measure of freedom of movement, find themselves subjected to

* Gordon N. Bardos is Assistant Director of the Harriman Institute at Columbia University.

1 Failure to Protect: Anti Minority Violence in Kosovo, March 2004 (New York: Human Rights Watch, July 2004), 2-3; emphasis added.

2 Assessment of the Situation of Ethnic Minorities in Kosovo (period covering October 2000 through February 2001), UNHCR and OSCE Mission in Kosovo, March 2001, Executive Summary. 
both direct and indirect discrimination when seeking access to basic civil, political, social, economic, and cultural rights. ${ }^{3}$

Thus, in $21^{\text {st }}$-century Europe, in a province administered by the United Nations, individuals in Kosovo towns such as Kisa are living behind barbed wire. The impotent monitoring of violence against ethnic minorities, however, is only one item in a long list of the international community's failings in Kosovo. But since failure is not an excuse for not having a policy, the question remains, What should the international community do about Kosovo? Some argue that the current status quo in the province is untenable and that moving towards independence is the only feasible political option. In reality, however, as will be argued below, the current thrust of international policy, intent on maintaining a strict "standards before status" approach regarding the Serbian province's future, is the only realistic policy available for Kosovo for three reasons.

First, there are simply no responsible institutions or individuals in Kosovo to whom sovereignty could be transferred. The actions of Kosovo's political leaders, security organizations, and civil society institutions over the past five years have shown that none are capable of creating a state that will respect the rights of non-Albanian ethnic communities or the security of neighboring states.

Second, everything we have learned in the Balkans over the past fifteen years during the breakup of Yugoslavia, and especially over the past five years in Kosovo, shows that a spillover effect is very much in operation in southeastern Europe. Granting independence to Kosovo would very seriously endanger the future viability of Macedonia, the stability of southern Serbia's Presevo Valley, the still-shaky Dayton Peace Process in Bosnia-Herzegovina, and could complicate the still unresolved process of state-building in Albania itself.

Third, in a province with such a weak economy and such poorly developed institutions, the possibility that organized crime or terrorist organizations like Al-Qaeda could take control of the province would increase considerably, creating a potential Afghanistan in Europe's backyard.

Finally, the Kosovo case is important for another reason. In the debates over U.S. policy and the Iraq war, some argue that Kosovo is an example of how Iraq "should have been done." Former State Department spokesman Jamie Rubin, for instance, claimed "Kosovo has been a success." Such a mindset inevitably led many people to believe that other interventions could similarly "succeed." Yet any truthful, intelligent, and serious examination of the aftermath of the Kosovo intervention inevitably leads to precisely the opposite conclusion. To avoid the mistakes of the Kosovo operation from being made again in other parts of the world, we must ignore the hype of bureaucratic spin-masters and gain a more realistic understanding of the complexities of intervention, ethnic conflict, and state-building in the Balkans.

3 "Serbia and Montenegro (Kosovo/Kosova) 'Prisoners in our own homes': Amnesty International's Concerns for the Human Rights of Minorities in Kosovo/Kosova" (Amnesty International, May 2003), Introduction.

4 See James P. Rubin, "Honoring Nation-Building," Washington Post, 19 October 2004, A23. 


\section{The Case for Containment}

Since 1999, the international community has been engaged in what (until the Iraq conflict) had been considered the most expensive effort in democratization and statebuilding yet attempted. According to one estimate, Kosovo has received "more money, aid and support than any other war-ravaged country."5

Yet even this tremendous international effort, in an area no larger than greater Los Angeles and with a population of only two million people, has achieved none of its stated goals. Kosovo remains wracked by innumerable social, political, cultural, ethnic, and security problems, all of which the international community has been practically impotent to solve. Kosovo's current unemployment rate is estimated to be as high as seventy percent. ${ }^{6}$ Kosovo's governmental institutions have little ability to raise revenue on their own; as a recent report by the International Crisis Group (ICG) notes, "the majority of Kosovo Albanian individuals and businesses fail to pay their utility bills and consumer taxes." "The flow of drugs through Kosovo has increased since NATO took control of the province, as has Kosovo's importance as a transit point in the trafficking of women from Eastern European countries to brothels in Western Europe. ${ }^{8}$ Five years after the war, the United Nations Interim Mission in Kosovo (UNMIK) still has not satisfied even the most basic infrastructural needs of the province; large parts of Kosovo, including the main city, Pristina, remain plagued by water shutoffs and electricity blackouts several hours a day. As one analyst has noted, "Infrastructure such as electricity and water actually run slightly worse than they did under Serbian rule."

Kosovo residents are right in claiming that this is due in large part to UNMIK's incompetence and corruption. Yet this state of affairs is part of a larger story plaguing Kosovo: the fact that Kosovo on its own is not an economically viable entity, and the overall weakness and corruption of Kosovo's own institutions and leadership. Given these problems, any hasty changes to Kosovo's status will in all likelihood have significant negative spillover effects throughout the region. They could also lead to a se-

5 As reported by Helena Smith, "Angry Kosovars Call on 'Colonial' UN Occupying Force to Leave," The Observer (London), 19 October 2003.

6 As cited by Jehona Gjurgjela, "Kosovo: Murders Expose Divided Community," IWPR's Balkan Crisis Report, 24 January 2003.

7 As cited in Collapse in Kosovo (Pristina/Belgrade/Brussels: International Crisis Group), 22 April 2004, 38. The same problem holds true for Albanian-populated areas in neighboring Macedonia. According to one report, more than half of the citizens of Tetovo do not pay their electricity bills. See "Macedonia: No Room for Complacency." Skopje/Brussels: International Crisis Group Europe, Report No. 149, 23 October 2003, 16.

8 Maggie O'Kane, "Kosovo Drug Mafia Supply Heroin to Europe," The Guardian Unlimited, 13 March 2000. By 2002, Albanian criminal gangs in Britain, for instance, were estimated to control 75 percent of the brothels in London. Many Albanian criminals enter Britain posing as Kosovo Albanian refuges. See Stewart Tendler, "Albanian Gangs Use Balkan Violence to Invade Underworld," The Times (London), 25 November 2002, p. 10.

9 See the comments of Nicholas White, as cited by Robert McMahon, "Kosovo: Under Mounting Criticism, UN Considers Changes to Policy," Radio Free Europe/Radio Liberty Feature Article, 13 August 2004. 
curity vacuum that could potentially affect Western Europe and the United States as well.

\section{The Weakness of Kosovo Institutions}

A report by the ICG on the March pogroms claimed that Kosovo is:

... deeply troubled, lacking institutions, leadership and the culture to absorb shocks and contain its violent, criminal minority ... the inadequate responses of Kosovo Albanian politicians, media and society to the violence have also demonstrated Kosovo's lack of readiness for final status.... State experience, habits and skills are lacking at all levels.... The three political parties have essentially consumed the government, divvying up and factionalizing the ministries, subjecting government to their patron-client networks, leaving little space for an independent civil service to emerge.... The Kosovo Provisional Institutions of Self-Government (PISG) cannot bring themselves to give direction to the society they purport to represent. ${ }^{10}$

This is not the opinion of international onlookers alone. Even by their own constituency, Kosovo's politicians are widely seen as corrupt and lacking the skills to govern effectively. ${ }^{11}$

Part of this is due to the fact that, given Kosovo's social structure, the lines between organized crime groups trafficking in arms, drugs, and human beings, and "legitimate politicians" is blurred. In January 2000, UN police raided the apartment of the brother of Hashim Thaci, the former political leader of the Kosovo Liberation Army (KLA) and currently president of the second-largest political party in Kosovo. In the apartment, police discovered DEM 500,000 in cash, the proceeds of various racketeering activities. ${ }^{12}$ In April 2002, a witness in the trial of the so-called "Dugagjini Group," Ilir Selimaj, was murdered in western Kosovo. Among those arrested for the murder was the leader of the Dugagjini Group, Daut Haradinaj, the brother of Ramush Haradinaj, the leader of the third-largest political party in Kosovo. As one senior U.S. Army officer described the structure of power in Kosovo, "We call it a thugocracy. The mafia, the politicians, and the so-called freedom fighters are all connected." 13

What is also clear is that, given Kosovo's conservative, patriarchal society, things such as the March pogroms do not just happen "spontaneously." Even before the wave of violence in March, UN Secretary-General Kofi Annan had called the new ethnic cleansing of Kosovo "orchestrated," while a top U.S. official described it as "system-

${ }_{10}$ Collapse in Kosovo, i, 30, 34.

11 See the interview with Professor Enver Hasani, “An Uncertain Future," Transitions Online, 26 February 2004, available at www.tol.cz.

12 Lutz Kleveman, "Brothers in Arms Fall Out Over Spoils of Kosovo," The Electronic Telegraph, 12 June 2000.

13 See Roberto Suro, "In Kosovo, an Uncertain Mission," Washington Post, 20 September 2000, A01. Similarly, General Fabio Mini, who was commander of KFOR between October 2002 and October 2003, believed that organized crime networks, Kosovo Albanian traditional social structures, the KLA and its successor structure, the Kosovo Protection Corps, were largely interchangeable. See Collapse in Kosovo, 8. 
atic." ${ }^{\prime 4}$ After a particularly deadly terrorist attack on a bus in February 2001 in which eleven people were killed, a joint UNHCR/OSCE report on the condition of ethnic minorities in 2001 pointed out: "It would appear there is an orchestrated campaign, or campaigns by, as yet, unidentified elements whose aim is clearly to terrorize minority populations, destabilize the province, and prevent democratization and peaceful coexistence." 15

Recent events fully bear out this assessment of the violence in Kosovo as being systematically planned and orchestrated. UN Secretary-General Kofi Annan, in his report to the UN Security Council on the March pogroms in Kosovo, noted that, "The onslaught led by Kosovo Albanian extremists against Serb, Roma, and Ashkali communities of Kosovo was an organized, widespread, and targeted campaign." "Human Rights Watch observed that, "Once the violence began, it swept through Kosovo with almost clinical precision: after two days of rioting, every single Serb, Roma, or Ashkali home had been burned in most of the communities affected by violence, but neighboring ethnic Albanian homes were left untouched." 17

Indicative of the amount of control Kosovo Albanian leaders exerted over the rioters, on the second day of the Kosovo pogroms international officials noted with cynicism how Kosovo Prime Minister Rexhepi was able to disband a supposedly unruly mob in less than two minutes. ${ }^{18}$ As the pogroms were beginning, the Kosovo Assembly (overwhelmingly dominated by Albanian representatives) issued a statement blaming the international community and Serbs for the violence. Not a single leading Albanian political leader was willing to forthrightly condemn attacks on non-Albanian ethnic groups for days. ${ }^{19}$ Yet no one should have been surprised at the March violence. After

14 "Report of the Secretary-General on the United Nations Interim Administration in Kosovo," s/2000/538, 6 June 2000. The comments by the U.S. official, James O'Brien, can be found in George Jahn, “Anti-Serb Violence Condemned," Associated Press, 8 June 2000.

15 Assessment of the Situation of Ethnic Minorities in Kosovo (period covering October 2000 through February 2001), UNHCR and OSCE Mission in Kosovo, March 2001, Executive Summary; emphasis added.

16 UNSC S/2004/348, 30 April 2004, as cited in the Amnesty International report, "The March Violence: KFOR and UNMIK's failure to protect the rights of the minority communities." (Amnesty International: AI Index EUR 70/016/2004), 2; emphasis added. KFOR officials concur in the view that the March pogroms were a well-organized campaign. KFOR spokesman Lt. Col. James Moran told Amnesty International that KFOR had found "bus loads of organizers traveling from town to town." See "The March Violence," 21.

17 Failure to Protect: Anti Minority Violence in Kosovo, March 2004, 28; emphasis added.

18 Collapse in Kosovo, 49. Further pointing to the systematic nature of the March violence was the fact that supposedly unruly mobs were very picky in their targeting, carefully choosing only UNMIK vehicles to destroy, while bypassing OSCE, EU, and UNHCR vehicles. After noting that there were some all-too-rare efforts by local Albanian leaders to restrain the mobs, Human Rights Watch noted that "these sporadic actions beg the question of how much more destruction could have been prevented if the entire Kosovo Albanian leadership had taken a more proactive approach to seeking to end the violence, rather than initially justifying it as some politicians did." Failure to Protect, 61.

19 Failure to Protect, 58. 
the first set of demonstrations in postwar Kosovo against the international presence in October 2003, Rexhepi very clearly put the international community on notice, ominously warning that the demonstrations were "just the beginning.","20

The corruption of the political establishment, and its toleration of and support for the persecution of ethnic minorities in Kosovo, is mirrored in other institutions as well. For example, freedom of the press in Kosovo takes some disturbing forms. On 27 April 2000, a newspaper linked to Hashim Thaci accused a Serb working for UNMIK of being a war criminal, and published his photograph, address, and workplace. Two weeks later, the individual in question was stabbed to death. ${ }^{21}$ Despite the millions of dollars spent on professional development programs for Kosovo's media over the past five years, little has improved. In the aftermath of the March pogroms, the OSCE noted that Kosovo's media had engaged in "reckless and sensationalist reporting," displayed "an unacceptable level of emotion, bias, and carelessness," and were deserving of "the strongest criticism." 22

It was revealed in 2002 that patients at UN-run mental health facilities in Kosovo have been raped and physically attacked in front of UN staff. Dr. Robert Okin, author of a report written by Mental Disability Rights International (MDRI), charged that the $\mathrm{UN}$ in Kosovo "had disregarded its own standards for the protection and treatment of the mentally disabled and turned a blind eye to the evidence" of abuse at Kosovo's two mental health institutions. According to Dr. Eric Rosenthal, the founder of MDRI, "This is a pervasive pattern of serious abuses. The rule of law simply does not apply within these psychiatric facilities. We found extreme, inhuman, and degrading treatment, arbitrary detention and the physical and sexual assault of women, and we received a blanket denial from the authorities."23

Similar problems exist in Kosovo's educational institutions. In September 2002, the coordinator of UNMIK's science and education efforts in Kosovo, Michael Daxner, announced he was leaving his post because it was proving impossible to stop discrimination against non-Albanians in Kosovo's schools. ${ }^{24}$

Perhaps most serious, however, has been the poor performance of Kosovo's legal system. As one analysis of Kosovo's judicial system notes, "Five years after an international-led administration was set up in Kosovo, the judicial system, and especially the municipal courts, are almost grinding to a halt, unable to deal with the load of cases

20 As reported by Helena Smith, "Angry Kosovars Call on 'Colonial' UN Occupying Force to Leave," The Observer (London), 19 October 2003.

21 R. Jeffrey Smith, "U.N. Halts Publication of Kosovo Newspaper," Washington Post, 4 June 2000, A22. See also Danica Krka, "Kosovo Media Practice Targeted," Associated Press, 30 May 2000.

22 As reported in "Media 'Inflamed' Riots," IWPR's Balkan Crisis Report, No. 494, 30 April 2004.

23 Oliver Burkeman, "UN 'ignored' abuse at Kosovo mental homes," The Guardian (London), 8 August 2002.

${ }^{24}$ Quirin Schiermeier, “Kosovo's Ethnic Divide Blights UN Science Rebuilding Plans," Nature 419 (19 September 2002). 
that has been filed." ${ }^{25}$ In the first year of NATO's occupation of the province, over 500 murders were committed, yet Kosovo's court system has failed to return a single conviction. ${ }^{26}$ In most cases, Albanian police officers and judges simply refuse to prosecute or investigate crimes against non-Albanian ethnic communities. Among police, as a 2003 UNHCR report noted, "Even when KFOR detains a perpetrator, and he/she is handed over to the police, the case will not be filed or followed up., 27

But the shortcomings of Kosovo's indigenous police units are more serious than just passively watching crimes being committed against non-Albanians. In many cases, the institutions charged with maintaining security in the province have been accused of participating in such actions. For instance, the Kosovo Protection Service (KPS, the local police service) was implicated in a significant number of attacks during the March pogroms. ${ }^{28}$

And, in Kosovo's ethnically biased court system, as a spokesperson for Amnesty International noted,

Despite the appointment of international prosecutors and judges to the Kosovo courts, the judicial system in Kosovo continues to be seriously flawed.... From cases of unlawful pre-trial detention to procedural breaches in the conduct of trials, the administration of justice fails to be conducted in a manner consistent with international human rights standards. ${ }^{29}$

The shortcomings of Kosovo's justice system are compounded by the fact that, even when there are witnesses to a crime, no one agrees to cooperate with police investigations. In January 2003, another witness in the trial of the aforementioned "Dugagjini Group," Tahir Zemaj, was gunned down in the middle of Pec, along with two family members. Although there were forty people on the street at the time of the murder, "the dozens of witnesses claimed they saw nothing."

25 See Mevlyde Salihu, "Kosovo: Overloaded Courts Grind to a Halt," IWPR's Balkan Crisis Report No. 511, 12 August 2004.

26 Steven Erlanger, "UN Official Warns of Losing the Peace in Kosovo," New York Times, 3 July 2000, A3.

27 "UNHCR Update on the situation of Roma, Ashkali, Egyptian, Bosniak and Gorani in Kosovo," January 2003, 8.

28 "The March Violence," 8-10. See also the Human Rights Watch report, Failure to Protect, for various descriptions of either KPS passivity during the violence, participation in it, or the rare instances of KPS officers trying to protect members of Kosovo's non-Albanian ethnic communities.

See Nicholas Wood, "Amnesty and UN staff accuse Kosovo war crimes tribunal of ethnic bias," The Guardian (London), 20 June 2001.

30 Hugh Griffiths, "(UN) Protected Witnesses," Transitions Online, 19 June 2003, available at www.tol.cz. See also Jeta Xharra and Tanja Matic, "Kosovo: Police Face Wall of Silence," Institute for War and Peace Reporting, Balkan Crisis Report, No. 455, 21 August 2003. 
Pristina noted, these assassinations "prevent Kosovo from meeting the standards it must achieve before final status can be discussed." 31

With the breakdown of law and order in Kosovo and the absence of a functioning legal system, a brutal medieval Albanian legal code, known as the Kanun of Lek Dukagjini, has again started to appear in Kosovo society. The Kanun sanctions such things as blood feuds between various clans and families and the treatment of women as chattel property. In one particularly gruesome incident, a young Kosovo bride in an arranged marriage was returned to her family by her husband of twelve hours after he decided that she was not a virgin. Upon her return to her family, her oldest brother (a former KLA member) murdered her in the presence of her mother and sister for bringing shame on the family. A postmortem autopsy showed that the woman was in fact a virgin. $^{32}$

\section{Independent Kosovo: The Afghanistan of Europe?}

Despite the fact that the Muslim populations in Bosnia, Kosovo, and Albania are probably the most pro-Western Islamic groups in the world, the Balkan wars over the past decade provided an opportunity for foreign Islamic radicals to infiltrate the region, recruit local Muslim sympathizers, and develop an extremist network that can threaten Kosovo itself, other states in South-Eastern Europe, and even Western Europe and the United States.

In the 1990s, Osama Bin Laden began setting up terrorist training camps in the northern Albanian town of Tropoje, while some KLA members - a group Timothy Garton Ash once colorfully described as "a bunch of farmyard Albanian ex-MarxistLeninist terrorists" 33 — were taken to Afghanistan for training. ${ }^{34}$ By February 1998, the top U.S. Balkan envoy at the time, Ambassador Robert Gelbard, noted that "the KLA is without any question a terrorist group." 35 Bin Laden was at this time reported to have struck a deal with Iran's Revolutionary Guards to support the KLA's activities in the hope of turning the region "into their main base for Islamic armed activity in Europe." 36

31 According to Reno Harnish, head of the U.S. Office in Pristina, as cited by Arben Qirezi, "Kosovo: Witness Protection Fears Grow," Institute for War and Peace Reporting, Balkan Crisis Report No. 426, 29 April 2003.

32 Christian Jennings, "Medieval murder marks tragedy of Kosovo," The Scotsman, 26 August 2002.

33 See Timothy Garton Ash, "Kosovo: Was It Worth It?" The New York Review of Books, 21 September 2001, 53.

34 "KLA Rebels Train in Terrorist Camps," Washington Times, 4 May 1999. See also Chris Hedges, “Kosovo’s Next Masters?” Foreign Affairs 78 (May/June 1999): 39.

35

36 Uzi Mahnaimi, "Iranians Move In," The Sunday Times (London), 22 March 1998. This attempt to join forces with Iran in the Balkans appears to have been part of Bin Laden's broader effort to increase cooperation between Al-Qaeda and Iran during this period, but Iranian opposition to the Taliban government apparently made such an alliance impossible. 
U.S. military raids on Al-Qaeda camps in Afghanistan in October and November 2001 turned up considerable evidence of the connections between Osama Bin Laden and Al-Qaeda volunteers from Albania, Bosnia, and Kosovo. One document made public was a letter written by Damir Bajrami, a Kosovo Albanian, suggesting new targets of opportunity in Western countries:

I am interested in suicide operations. I have Kosovo Liberation Army combat experience against Serb and American forces. I need no further training. I recommend (suicide) operations against (amusement) parks like Disney. ${ }^{37}$

The Bin Laden network and its operatives within the KLA are still active within Kosovo. In December 2003, NATO forces arrested a KLA deputy commander, Niam Behljulji, after he had attempted to sell 13.5 kilograms of Semtex (a powerful explosive favored by suicide bombers) to a group of British journalists posing as members of the Real Irish Republic Army. Behljuhlji and his group within the KLA had been trained by Al-Qaeda. The Semtex they tried to sell was powerful enough to have destroyed the houses of Parliament in London or to bring down forty jumbo jets. ${ }^{38}$

Kosovo in recent years has also attracted significant attention from Saudi- and Iranian-based charity groups active in developing a network of schools propagating extremist/Wahhabist versions of Islam. According to one estimate, almost 100 primary and secondary schools have been built by Saudi groups alone in rural areas of Kosovo over the past several years and, as one regional specialist points out, it was the Koranic schools in Pakistan in the 1980s that eventually produced the Taliban. ${ }^{39}$

Clearly, the political establishment in Kosovo has little desire (or ability) to confront their criminal and/or Islamic extremist sponsors. Without an international force maintaining security, an independent Kosovo would become the Afghanistan of Europe: a mafia paradise and a failed state playing host to extremist groups determined to destabilize not just the southern Balkans, but Western Europe and the United States as well.

In addition to the dangers posed to Balkan stability by Islamic extremists operating in Kosovo, a related danger is the threat posed by Albanian organized crime groups based in Kosovo and Albania to Western Europe and the United States. Western intelligence agencies determined that, by the 1990s, the Albanian mafia had become "the most powerful group in the distribution of heroin in Western countries." criminal groups already control up to seventy percent of the heroin market in Germany and Switzerland and have taken control of prostitution rings (based on trafficking in

37 Jack Kelley, “Bin Laden's training camps teach curriculum of carnage," USA Today, 26 November 2001, $1 \mathrm{~A}$.

38 See Graham Johnson, "We buy bag of Semtex from terrorists," The Daily Mirror (London), 8 December 2003.

39 See Isa Blumi, "Competing for the Albanian Soul: Are Islamic Missionaries Creating a Lebanon in the Balkans?" Woodrow Wilson International Center for Scholars Meeting Report \#260, available at: www.wilsoncenter.org.

40 Roger Boyes and Eske Wright, "Drug Money Linked to Kosovo Rebels," The Times (London), 24 March 1999. 
human beings) in Britain as well. ${ }^{41}$ In August 2004, the Federal Bureau of Investigation (FBI) announced that criminal groups made up of individuals from Kosovo, Macedonia, and Montenegro had practically overtaken the role of La Cosa Nostra crime families along the Eastern seaboard of the U.S. The FBI is investigating whether this predominantly Albanian Muslim criminal network may be linked to wider international terrorist financing operations. ${ }^{42}$ Considering these realities, giving Kosovo independence would in effect be giving these criminal syndicates a free base of operations in the middle of Europe.

\section{Spillover Effects}

The history of the Balkan conflicts since the early 1990s shows that spillover is a very real threat in the region. In 1992, the recognition of Slovenia and Croatia directly led to war in Bosnia and Herzegovina; in 1999, the NATO intervention on behalf of the KLA directly resulted in Kosovo's extremists continuing their efforts in southern Serbia and Macedonia. And, as was seen in the March pogroms, when Serbian churches start burning in Kosovo, mobs start burning mosques in Belgrade, and when mosques start burning in Belgrade, extremists start burning Christian churches in Bosnia.

Nowhere has this threat of spillover been more evident than in the aftermath of the Kosovo war. After NATO occupied Kosovo, extremists within the province set their sights on new targets: the Presevo Valley in southern Serbia and the neighboring province of Macedonia. After it became clear that numerous KLA members were involved in this violence, on 27 June 2001, U.S. President Bush signed an Executive Order that claimed, among other things, that several high-ranking KLA members were engaging in actions that "constitute an unusual and extraordinary threat to the national security and foreign policy of the United States." ${ }^{\text {"43 }}$ Five of the individuals on President Bush's list, including the Kosovo Protection Corps' chief of staff, were on the UN payroll. Another offshoot of the KLA, the so-called "Albanian National Army," which is currently active in Kosovo and Macedonia, was declared a terrorist organization by the $\mathrm{UN}$ in 2003 . $^{44}$

Macedonia has yet to recover from the near-miss civil war of 2001-02. With the Dayton Peace Process in Bosnia-Herzegovina still far from consolidated, and given the continued problems in creating a viable state in Albania itself, moving toward final

41 As cited by Frank Cilluffo and George Salmoiraghi, "And the Winner is ... the Albanian Mafia," The Washington Quarterly 22 (Autumn 1999): 23; see also Michael Steiner, "Fight Crime at its Source," La Libre Belgique (Brussels), 1 June 2002; Jason Bennetto, "Albanians 'taking over London vice',' The Independent (London), 25 November 2002.

42 Terry Frieden, "FBI: Albanian mobsters 'new Mafia'," available at www.cnn.com/2004/ LAW/08/18/albanians.mob/index.html.

43 "Executive Order Blocking Property of Persons Who Threaten International Stabilization Efforts in the Western Balkans" (Washington, D.C.: The White House, 27 June 2001). See also "UN Suspends Five Top Members of Kosovo Civil Corps," Agence France-Presse, 6 July 2001.

44 Radio 21 (Pristina), 17 April 2003. 
status for Kosovo at this point in time would have severe negative consequences for the entire southern Balkans. The grand old man of Balkan politics, former Macedonian president Kiro Gligorov (the one leader in the former Yugoslavia who managed to withdraw his republic from the collapsing federation without a shot being fired), recently warned that granting Kosovo independence would in fact "set the Balkans on fire. ${ }^{45}$

\section{The Moral Case for Containment}

Distinct from all of the practical reasons for delaying a move toward final status for Kosovo at this time is the moral case, particularly the lesson that would be sent if extremists in Kosovo were seen to have been successful in achieving their aims. Over the past five years in Kosovo - on NATO's watch, it must be kept in mind - extremists have driven over 200,000 people from the province, abducted 1,200 individuals from their homes, and destroyed over 130 Christian churches in the most sustained campaign of ethnic persecution in Europe since World War II. In the Bosnian conflict, the international community decided that actions by individuals and groups perpetrating such offenses would not be rewarded. It would be the height of hypocrisy if the international community were now to adopt a different position. As the EU's foreign policy representative, Javier Solana, noted during a visit to Kosovo immediately after the violence, "burning churches, burning schools, chasing people out of their homes is [sic] not the type of standards that the European Union is defending."

Given the record of the past five years, Kosovo's leaders and society have shown that Kosovo is very, very far from being a place where values such as respect for the rule of law and the rights of different ethnic communities have any meaning. The March pogroms provided further evidence of the need for tremendous change in Kosovo Albanian society before serious moves towards final status can be considered. As the ICG summarized its report on the March violence:

... the inadequate responses of Kosovo Albanian politicians, media, and society to the [March] violence have also demonstrated Kosovo's lack of readiness for final status .... in its present condition, Kosovo Albanian society contains insufficient checks and barriers to prevent it from gradually expelling all foreign bodies within its midst or in its path - whether they be Serbs, other minorities, or internationals. Ultimately, there is a risk that it will destroy or expel its own Albanian non-conformist minorities (the Kosovo Albanian Catholic minority is already much reduced by emigration) and tiny liberal elites. ${ }^{47}$

Clearly, neither Kosovo's political establishment nor Kosovar society can deal with the scale of the problems that confront the province. Consequently, the international community must develop a new set of policies to protect non-Albanian ethnic groups in

\footnotetext{
45 RFE/RL Newsline, 8 October 2003.

46 As quoted in Failure to Protect, 27, footnote 64.

47 Collapse in Kosovo, 30-32.
} 
the province and to contain the threat to the southern Balkans that presently emanates from Kosovo.

\section{Policy Prescriptions}

Five years after the Kosovo war, the international community now finds itself in an unenviable position. It can give in to popular and social pressures within Kosovo for independence, share the moral responsibility for the ethnic persecution that has taken place in Kosovo since 1999, and wash its hands as extremists destabilize the southern Balkans and create a security vacuum in which organized crime syndicates and terrorist organizations can thrive. This policy option carries with it the advantage of not bringing the international community into conflict with the majority population in Kosovo.

If we believe, however, as Nicholas Whyte has argued, that the actions of Kosovo's political class and society at large have "disqualified [Kosovo] from independence,"48 then it is clear that the Kosovo problem must be contained, because independence for Kosovo would inevitably create a far larger regional problem down the line. Although this policy option bears the risk of bringing the international presence in Kosovo into direct confrontation with extremists in the province, several things can be done to mitigate these dangers.

First, and most importantly, NATO and the UN must build up the courage and determination to deal with Kosovo's extremists. A common perception among observers, as one report noted, is that "[UNMIK] has deliberately delayed tackling the problem of Albanian violence against Serbs. Many put this down to a desire to avoid conflict with the majority population." 49 But, given the nature of Kosovo Albanian society, removing the leaders of the campaign against non-Albanian ethnic communities in the province would do much to bring this violence to an end. While moving forcefully against the ringleaders of the campaign to create an ethnically "clean," homogeneously Albanian province will not lead to an upwelling of interethnic harmony between the various ethnic groups in Kosovo, it will at least prevent a repeat of the March pogroms, and will help rein in extremists fomenting violence in neighboring states.

A lesson from international strategy in nearby Bosnia is suggestive in this regard. In May 2001, after rebuilding ceremonies for two mosques in the Republika Srpska (RS) were disrupted by violent mobs, within days international officials had purged the RS's entire Interior Ministry. More recently, in July 2004, the High Representative in Bosnia-Herzegovina removed sixty public officials from office, including the president of the national assembly and the interior minister, for allegedly being involved in a network aiding Radovan Karadzic.

Yet in Kosovo, despite the fact that twenty people were killed, thirty-six Christian churches and monasteries were destroyed, numerous offices and vehicles belonging to

48 See the comments by Nicholas Whyte, director of the International Crisis Group's Balkan program, as cited by Ines Sabalic, "Kosovo Independence Ruled Out," Institute for War and Peace Reporting, Balkan Crisis Report, No. 358, 14 August 2002.

49

See Tanja Matic, "Kosovo: Crimes Against Serbs Investigated," Institute for War and Peace Reporting, Balkan Crisis Report No. 468, 13 November 2003. 
international organizations were vandalized, and four thousand people were left homeless, a full six months later not a single individual of any consequence has been held accountable for the violence. As Amnesty International has repeatedly warned over the past several years, UNMIK and KFOR's policy of allowing extremists to kill at will has created a "culture of impunity" in Kosovo, in which the international community is passively monitoring the very campaign of ethnic persecution it appointed itself to prevent.

Second, it is clear that Albanian politicians in Kosovo have been completely unwilling to secure even a modicum of basic human and civil rights to Kosovo's non-Albanian ethnic groups. Over the past five years - again, on NATO and the United Nations' watch - nothing less than a system of ethnic apartheid has been created in Kosovo. This state of affairs completely disqualifies Kosovo's current leadership from being given the responsibility for governing or providing security for Kosovo's non-Albanian ethnic communities. Consequently, decentralizing Kosovo's political structure has become imperative. A number of plans are now under examination, but regardless of which plan is ultimately adopted, it is clear that the international community will have to continue monitoring security in the province and playing a large role in governance.

Finally, the international community must also do more to counter the efforts of Saudi and Iranian extremist groups to recruit new generations of disaffected Muslim youth in Kosovo to their cause. While much international aid goes to urban areas, Middle Eastern organizations have found that rural areas of Kosovo are ready recipients of both their aid and ideology. International development strategies must be reconceptualized before Kosovo Albanian society becomes dominated by rural Islamic fundamentalists.

Whether the international community can or will do any of these things remains to be seen. The record of the past five years - a record of hypocrisy, double standards, and empty talk - certainly provides little hope for optimism. Yet after having gone to war and killing hundreds of civilians ostensibly to create a multiethnic democracy in Kosovo, history will not judge NATO or the United Nations kindly if Kosovo continues down the road of becoming $21^{\text {st }}$-century Europe's only apartheid para-state. 
THE QUARTERLY JOURNAL

\section{Bibliography}

Ash, Timothy Garton. "Kosovo: Was It Worth It?" The New York Review of Books 21 (2001).

Battistelli, Fabrizio. "Peacekeeping and the Postmodern Soldier." Armed Forces and Society 23, no. 2 (1997).

Burkeman, Oliver. "UN 'ignored' abuse at Kosovo mental homes." The Guardian (2002).

Cilluffo, Frank, and George Salmoiraghi. "And the Winner is ... the Albanian Mafia." The Washington Quarterly (1999).

Erlanger, Steven. "UN Official Warns of Losing the Peace in Kosovo." New York Times (2000).

Franke, Volker C.. "Resolving Identity Tensions: The Case of the Peacekeeper." Journal of Conflict Studies (1999).

Gjurgjela, Jehona. Kosovo: Murders Expose Divided Community In IWPR's Balkan Crisis Report., 2003.

Hasani, Professor Enver. "An Uncertain Future." Transitions Online (2004).

Jennings, Christian. "Medieval murder marks tragedy of Kosovo." The Scotsman (2002).

Kleveman, Lutz. "Brothers in Arms Fall Out Over Spoils of Kosovo." The Electronic Telegraph (2000).

Qirezi, Arben. Kosovo: Witness Protection Fears Grow In Institute for War and Peace Reporting, Balkan Crisis Report . Vol. 426., 2003.

Rubin, James P.. "Honoring Nation-Building." Washington Post (2004).

Salihu, Mevlyde. Kosovo: Overloaded Courts Grind to a Halt In IWPR's Balkan Crisis Report., 2004.

Schiermeier, Quirin. "Kosovo's Ethnic Divide Blights UN Science Rebuilding Plans." Nature 419 (2002).

Smith, Helena. "Angry Kosovars Call on 'Colonial' UN Occupying Force to Leave." The Observer (2003).

Suro, Roberto. "In Kosovo, an Uncertain Mission." Washington Post (2000).

T. Bartone, Paul, Amy B. Adler, and Mark A. Vaitkus. "Dimensions of Psychological Stress in Peacekeeping Operations ." Military Medicine (1998).

Wood, Nicholas. "Amnesty and UN staff accuse Kosovo war crimes tribunal of ethnic bias." The Guardian (2001). 